Article

\title{
A Field Pilot Study on Treating Groundwater Contaminated with Sulfolane Using $\mathrm{UV} / \mathrm{H}_{2} \mathrm{O}_{2}$
}

\author{
Linlong $\mathrm{Yu}^{1}{ }^{1}$, Sobhan Iranmanesh ${ }^{1}$, Ian Keir ${ }^{2}$ and Gopal Achari ${ }^{1, *(\mathbb{D}}$ \\ 1 Department of Civil Engineering, University of Calgary, 2500 University Drive NW, Calgary, AB T2N 1N4, \\ Canada; linyu@ucalgary.ca (L.Y.); siranman@ucalgary.ca (S.I.) \\ 2 Bonavista Energy Corporation (formerly), 5258 Ave SW Suite 1500, Calgary, AB T2P 1G1, Canada; \\ Ian.Keir@bonavistaenergy.com \\ * Correspondence: gachari@ucalgary.ca; Tel.: +1-403-220-6599
}

Received: 3 April 2020; Accepted: 21 April 2020; Published: 23 April 2020

\begin{abstract}
Sulfolane is an emerging contaminant in the groundwater and soil nearby gas plants, which has attracted much attention from many researchers and regulatory agencies in the past ten years. In this paper, a field pilot-scale ultraviolet (UV)/hydrogen peroxide $\left(\mathrm{H}_{2} \mathrm{O}_{2}\right)$ system was investigated for treating sulfolane contaminated groundwater. Different groundwater, as well as different operational parameters such as influent sulfolane concentration, $\mathrm{H}_{2} \mathrm{O}_{2}$ dosage, and water flow rates, were studied. The results showed that a pilot-scale $\mathrm{UV} / \mathrm{H}_{2} \mathrm{O}_{2}$ system can successfully treat sulfolane contaminated groundwater in the field, although the presence of iron and other groundwater limited the process efficiency. The lowest electrical energy per order of reduction for treating sulfolane in groundwater by using the pilot-scale $\mathrm{UV} / \mathrm{H}_{2} \mathrm{O}_{2}$ system was $1.4 \mathrm{kWh} \mathrm{m}^{-3}$ order $^{-1}$. The investigated sulfolane initial concentrations and the water flow rates did not impact the sulfolane degradation. The enhancement of sulfolane degradation in an open reservoir by adding ozone was not observed in this study. Furthermore, an operational cost model was formulated to optimize the dosage of $\mathrm{H}_{2} \mathrm{O}_{2}$, and a stepwise procedure was developed to determine the power necessary of the UV unit.
\end{abstract}

Keywords: sulfolane; groundwater; pilot-scale; UV; hydrogen peroxide

\section{Introduction}

Sulfolane $\left(\mathrm{C}_{4} \mathrm{H}_{8} \mathrm{SO}_{2}\right)$, chemically known as tetrahydrothiophene-1,1-dioxide, is a stable, polar organic solvent, miscible with water, having extremely low vapor pressure and a high boiling point [1]. It is generally considered as a chemically and thermally stable compound. It had been extensively used in the Shell Sulfinol ${ }^{\circledR}$ process to remove $\mathrm{H}_{2} \mathrm{~S}$ and other polar compounds from natural gas and in the separation of aromatic compounds from aliphatic compounds. In the past several decades, inappropriate sulfolane waste disposal practices, leaks and spills during sulfolane production, storage, transportation, and use have led to significant groundwater contamination. Sulfolane has been detected in groundwater near oil and gas processing plants in North America and become a worldwide problem [2]. There are also media reports that sulfolane contamination has affected the water supplies of nearby farming communities in Alaska, US, and Alberta, Canada, thereby requiring alternate drinking water sources.

A comprehensive investigation on the impact of sulfolane on human health has not yet been reported, although there is an ongoing US national toxicology program on sulfolane, which was nominated in 2011. The limited toxicological data so far has shown that sulfolane might be a potential hazard to human health and the ecosystem. Zhu et al. [3] concluded that sulfolane can affect kidney, liver, and marrow functions in rats and guinea pigs. Gordon et al. [4] observed the inhibitory effect 
of sulfolane on the metabolic rate of rats. Shah et al. [5] reported that sulfolane can exert adverse effects on embryonic development of zebrafish. The impact of sulfolane pollution is strongly felt as it is miscible with water, leading to transport over long distances beyond the original source. A recognition of this problem, combined with the attention by regulators, has pushed sulfolane contamination issues to the forefront. In order to provide the public with safe drinking water, guidelines for sulfolane in the environment have been established in British Columbia (Canada), Alberta (Canada), and Texas (US).

Recent research has indicated that sulfolane in water can be treated using advanced oxidation processes (AOPs). Yu et al. [6] combined UV irradiation with $\mathrm{H}_{2} \mathrm{O}_{2}$ and $\mathrm{O}_{3}$ to degrade $100 \mathrm{mg} / \mathrm{L}$ of sulfolane in ultrapure water in a batch reactor and obtained first-order degradation rate constants for $\mathrm{UV} / \mathrm{H}_{2} \mathrm{O}_{2}$ and $\mathrm{UV} / \mathrm{O}_{3}$ equal to $1.7 \times 10^{-3} \mathrm{~s}^{-1}$ and $1.9 \times 10^{-3} \mathrm{~s}^{-1}$. Mehrabani-Zeinabad et al. [7] reported similar degradation rates by using $\mathrm{UV} / \mathrm{H}_{2} \mathrm{O}_{2}$ and $\mathrm{UV} / \mathrm{O}_{3}$ in a flow-through reactor and determined sulfate as the major degradation byproduct, released from the cleavage of sulfur heterocycles ring. Izadifard et al. [8] degraded $220 \mathrm{mg} / \mathrm{L}$ of sulfolane by using $3000 \mathrm{mg} / \mathrm{L}$ of persulfate activated with UV and observed a first-order degradation rate $\left(1.51 \times 10^{-3} \mathrm{~s}^{-1}\right)$ close to $\mathrm{UV} / \mathrm{H}_{2} \mathrm{O}_{2}$ and $\mathrm{UV} / \mathrm{O}_{3}$ processes. Brandao et al. [9] successfully degraded sulfolane in soil washing water by using $\mathrm{UV} / \mathrm{H}_{2} \mathrm{O}_{2}, \mathrm{UV} / \mathrm{O}_{3}$, and other advanced oxidation processes. Khan et al. [10] integrated $\mathrm{UV} / \mathrm{H}_{2} \mathrm{O}_{2}$ with activated sludge to treat sulfolane and found that overall hydraulic retention times can be significantly reduced. Nonetheless, these are lab-scale studies, and prior to application at commercial scale, pilot-scale studies on a real sulfolane contaminated site are needed. The highly active hydroxyl radicals (HO•) generated during advanced oxidation reactions can breakdown sulfolane rings and into smaller and less hazardous compounds to resulting mineralization $[7,10]$. A parametric study evaluating the effect of hydrogen peroxide dosage, light intensity, and the combination of different oxidants on the sulfolane degradation rate has been reported by $\mathrm{Yu}$ et al. [6]. These laboratory studies indicated that a combination of UV and $\mathrm{H}_{2} \mathrm{O}_{2}$ is a promising method to degrade sulfolane in aqueous media. Upon UV irradiation, hydrogen peroxide can yield hydroxyl radicals, which can attack the organic contaminants in the aqueous medium. It has been considered as an environmentally friendly technology as less toxic compounds are generated during the process. The pilot-scale $\mathrm{UV} / \mathrm{H}_{2} \mathrm{O}_{2}$ systems have been mostly applied in treating contaminants in the clean water matrices such as surface water and secondary wastewater effluent. Chu et al. [11] applied a pilot-scale $\mathrm{UV} / \mathrm{H}_{2} \mathrm{O}_{2}$ system to treat emerging contaminants in water that had undergone coagulation, flocculation, and ultrafiltration treatment units in Singapore's Choa Chu Kang Waterworks. De la Cruz et al. [12] and Miklos et al. [13] used a pilot-scale $\mathrm{UV} / \mathrm{H}_{2} \mathrm{O}_{2}$ system to degrade micropollutants in effluents from municipal wastewater treatment plants. Sarathy et al. [14] have used a pilot-scale $\mathrm{UV} / \mathrm{H}_{2} \mathrm{O}_{2}$ system to improve the biodegradability of natural organic matter in surface water. However, only a few pilot studies focused on groundwater remediation [15], where the dissolved organic matter and other constituents can limit the UV transmittance (UVT) and impact the process efficiency.

In this research, the performance of a pilot-scale $\mathrm{UV} / \mathrm{H}_{2} \mathrm{O}_{2}$ system on treating sulfolane contaminated groundwater is evaluated. The groundwaters with different characteristics were investigated. The effect of operational parameters such as sulfolane influent concentration, water flow rates, and hydrogen peroxide dosage on sulfolane degradation was examined. Ozone was introduced into the treatment system to examine whether it can enhance the sulfolane degradation in groundwater. So far, most pilot-scale $\mathrm{UV} / \mathrm{H}_{2} \mathrm{O}_{2}$ studies only focus on the calculation of electrical energy requirement for treating contaminants, which is one of the major operational costs for $U V / \mathrm{H}_{2} \mathrm{O}_{2}$ treatment. In this paper, an economic study considering the $\mathrm{UV} / \mathrm{H}_{2} \mathrm{O}_{2}$ operational cost was performed to optimize the treatment system. An operational cost function was developed, in which the input parameters include the unit cost of hydrogen peroxide, electricity and UV lamps, hydrogen peroxide concentration, and lifetime and efficiency of UV lamps. The function was furtherly used to minimize the total operational cost, optimize hydrogen peroxide concentration, and select a proper size of UV system to treat sulfolane in groundwater. 


\section{Method and Materials}

\subsection{Chemicals}

Sulfolane with 98\% purity was obtained from EMD Millipore (Burlington, VT, US). Dichloromethane (DCM) with $>99.8 \%$ purity, sodium thiosulphate with $>98 \%$ purity was obtained from Sigma-Aldrich Canada Co. (Oakville, ON, Canada). Sulfuric acid (95-98\%) was purchased from VWR (Edmonton, AB, Canada). Hydrogen peroxide $\left(\mathrm{H}_{2} \mathrm{O}_{2}\right.$, A.R. grade, 35\%) was purchased from ClearTech Industries Inc. (Edmonton, AB, Canada).

\subsection{Site Description and Contaminated Groundwater}

A sulfolane contaminated site in Alberta, Canada, was selected for the field pilot test. The site is surrounded by agriculture areas and with oil and gas developments. A gas plant commissioned on the site in 1978 processed sour gas until 2014 and produces natural gas and liquid condensate. The primary current facility infrastructure of the gas plant includes the main process area, the surface runoff control system, product storage, inlet separators, a flare system, a "bone" yard, and an acid gas injection system. Recently, sulfolane contamination has been observed in both groundwater and soil on the site. Several groundwater wells have been installed for sulfolane remediation. In this field test, three different groundwaters with very different characteristics were tested. The waters came from different sources, and their physical and chemical properties are described in Table 1 . Water I was pumped from a shallow groundwater well (12 $\mathrm{m}$ deep) using a submersible pump. Water II was pumped from a deep groundwater well (about $70 \mathrm{~m}$ deep). Water III was pumped from a shallow groundwater well (11 $\mathrm{m}$ deep) and then was pretreated by passing through an activated carbon column. The water from a shallow groundwater monitoring well contained more calcium, magnesium, manganese, and iron than that from the deep well.

Table 1. Physical and chemical properties of groundwater: Water I was from a 12-m-deep groundwater well; Water II was from a 70-m-deep groundwater well, and Water III was from a 11-m-deep groundwater well, pretreated by activated carbon (provided by Bonavista Energy corporation).

\begin{tabular}{clccc}
\hline Parameter & Units & Water I & Water II & Water III \\
\hline Hardness $\left(\mathrm{CaCO}_{3}\right)$ & $\mathrm{mg} / \mathrm{L}$ & 653 & 3.6 & 310 \\
Total Dissolved Solids & $\mathrm{mg} / \mathrm{L}$ & 671 & 554 & 370 \\
Conductivity & $\mathrm{S} / \mathrm{cm}$ & 1.13 & 0.992 & 0.68 \\
$\mathrm{pH}$ & & 7.75 & 9.07 & 8.52 \\
Alkalinity (Total as $\left.\mathrm{CaCO}_{3}\right)$ & $\mathrm{mg} / \mathrm{L}$ & 415 & 450 & 200 \\
Bicarbonate $\left(\mathrm{HCO}_{3}\right)$ & $\mathrm{mg} / \mathrm{L}$ & 506 & 457 & 230 \\
Sulphate $\left(\mathrm{SO}_{4}\right)$ & $\mathrm{mg} / \mathrm{L}$ & 113 & 21.1 & 77 \\
Chloride $(\mathrm{Cl})$ & $\mathrm{mg} / \mathrm{L}$ & 56.7 & 22.5 & 61 \\
Nitrate $\left(\mathrm{NO}_{3}\right)$ & $\mathrm{mg} / \mathrm{L}$ & 0.07 & $<0.044$ & 0.49 \\
Nitrite $\left(\mathrm{NO}_{2}\right)$ & $\mathrm{mg} / \mathrm{L}$ & $<0.033$ & $<0.033$ & 0.17 \\
Calcium $(\mathrm{Ca})$ & $\mathrm{mg} / \mathrm{L}$ & 177 & 1.1 & 48 \\
Magnesium $(\mathrm{Mg})$ & $\mathrm{mg} / \mathrm{L}$ & 51.4 & 0.22 & 47 \\
Potassium $(\mathrm{K})$ & $\mathrm{mg} / \mathrm{L}$ & 5.62 & 0.56 & 4.8 \\
Sodium $(\mathrm{Na})$ & $\mathrm{mg} / \mathrm{L}$ & 17.0 & 239 & 14 \\
Iron $(\mathrm{Fe})$ & $\mathrm{mg} / \mathrm{L}$ & 0.355 & $<0.06$ & 0.084 \\
Manganese $(\mathrm{Mn})$ & $\mathrm{mg} / \mathrm{L}$ & 0.678 & $<0.004$ & 0.018 \\
\hline
\end{tabular}

\subsection{A Field Pilot-Scale $U V / \mathrm{H}_{2} \mathrm{O}_{2}$ System}

An integrated $\mathrm{UV} / \mathrm{H}_{2} \mathrm{O}_{2}$ pilot-testing system is shown in Figure 1, which consisted of a reservoir, an electrical water pump, an $\mathrm{H}_{2} \mathrm{O}_{2}$ peristaltic pump, an $\mathrm{H}_{2} \mathrm{O}_{2}$ storage tank, and a UV unit. The reservoir, UV unit, and water pumps were integrated through flexible polyvinyl chloride (PVC) pipes. The UV unit (UV LOGIC 8AL20) was rented from Trojan Technologies (London, ON, Canada), which provided UV dosage comparable to commercial operating systems. The UV unit has a built-in "motionless" 
mixer (Statiflo Series 400, Statiflo International Ltd, Cheshire, UK), a UV chamber, a flow meter (Ultra Mag, UM 06-02, McCrometer, Hemet, CA, US), and a UV intensity monitor. The power consumption of the UV system was approximately $2140 \mathrm{~W}$. Eight germicidal (Hg vapour) lamps were housed in the UV chamber.

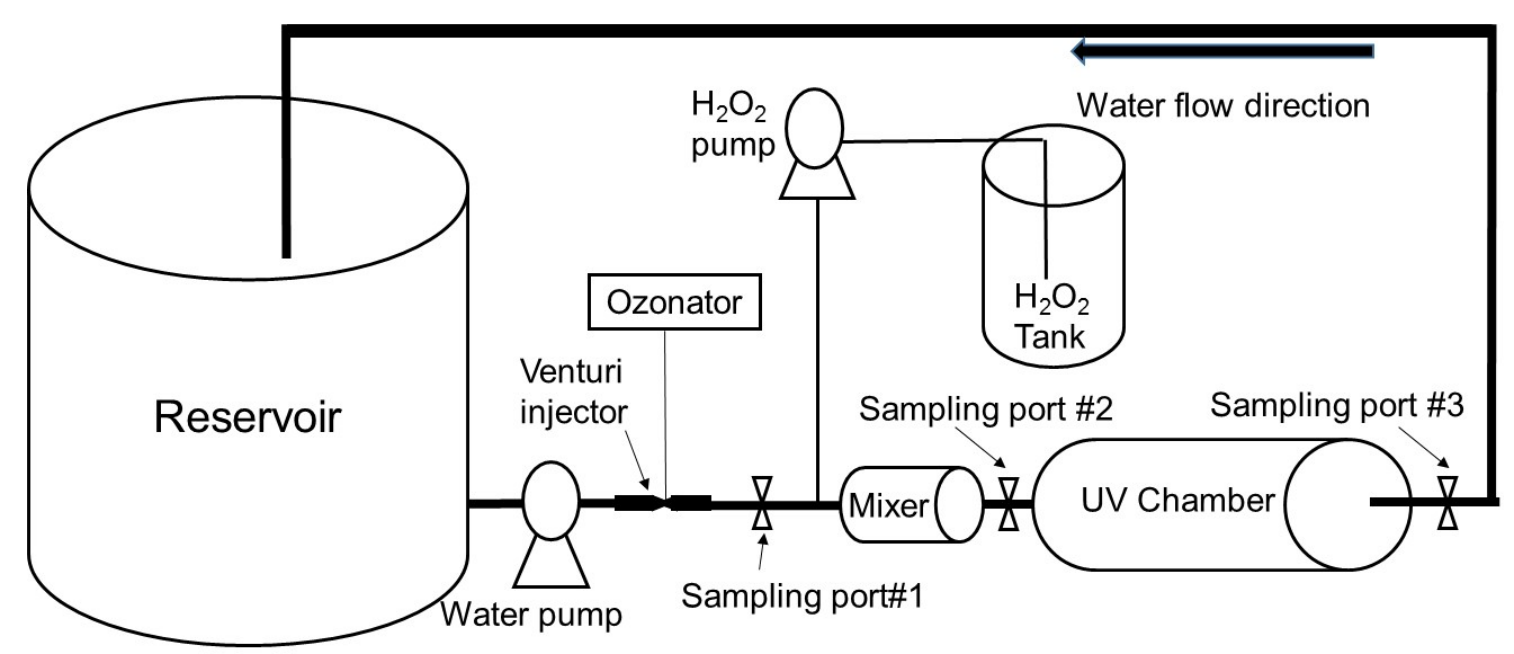

Figure 1. A schematic of a field pilot-scale $\mathrm{UV} / \mathrm{H}_{2} \mathrm{O}_{2}$ system being composed of an of high-density polyethylene (HDPE) reservoir, an electrical water pump, an $\mathrm{H}_{2} \mathrm{O}_{2}$ peristaltic pump, an $\mathrm{H}_{2} \mathrm{O}_{2}$ storage tank, and a Trojan UV unit.

The reservoir with a volume of $5.6 \mathrm{~m}^{3}$ was made of high-density polyethylene (HDPE). The water in the reservoir was pumped into the UV unit by using a variable controlled valve. Hydrogen peroxide from the storage tank was introduced through a peristaltic pump (Model ATN11V-4T, Blue-White Industry, Huntington Beach, WV, US). The amount of hydrogen peroxide injecting into the system can be adjusted by varying the $\mathrm{H}_{2} \mathrm{O}_{2}$ pump speed. Water was mixed with $\mathrm{H}_{2} \mathrm{O}_{2}$ by the mixer and then passed through the UV chamber. The water exiting the UV chamber was recirculated back to the reservoir, which was considered as "recirculation mode". For certain experiments, the water was not returned to the reservoir and these represented "single pass modes".

For ozone-related experiments, ozone was introduced to the system through a Mazzei Venturi injection system just prior to adding $\mathrm{H}_{2} \mathrm{O}_{2}$ (see Figure 1). An ozone generator (Guardian PB30s11wxxw) used in this study was rented from VEK Environmental (Edmonton, Canada). It produced ozone at a rate of $30 \mathrm{~g} / \mathrm{h}$.

\subsection{Testing Procedure}

For each test, three cubic meters of groundwater were pumped into the reservoir. The groundwater samples were further spiked with sulfolane by circulating at a high flow rate $(46 \mathrm{~L} / \mathrm{min})$ for one hour. The concentration of sulfolane after spiking is reported in each figure, which is considered as the initial concentration for each test. The UV unit was turned on and warmed up for 30 min before each test. The hydrogen peroxide dosage was adjusted based on the ratio of $\mathrm{H}_{2} \mathrm{O}_{2}$ flow rate to the water flow rate. There were three water sampling ports: (\#1) before adding $\mathrm{H}_{2} \mathrm{O}_{2}$, (\#2) after adding $\mathrm{H}_{2} \mathrm{O}_{2}$ but before the UV chamber, and (\#3) after the UV chamber. Samples were collected at varying time intervals. The valve was opened to flush the sampling port for $10 \mathrm{~s}$ prior to sampling $20 \mathrm{~mL}$ of water. Samples were quenched with $100 \mathrm{mg} / \mathrm{L}$ sodium thiosulfate, passed through a syringe filter of a $0.45-\mu \mathrm{m}$ polytetrafluoroethylene (PTFE) filter, preserved with $50 \mu \mathrm{L}$ of sulfuric acid and placed on ice prior to transportation for sulfolane and dissolved organic carbon (DOC) analysis. 


\subsection{Sulfolane and DOC Analysis}

Each $5.0 \mathrm{~mL}$ of water sample was extracted with $3.0 \mathrm{~mL}$ of DCM [10]. The sulfolane extraction efficiency was determined to be around $80 \% \pm 5 \%$. The extracts containing $>1 \mathrm{mg} / \mathrm{L}$ sulfolane were analyzed using an Agilent 6890 gas chromatography (GC) (Agilent, Santa Clara, CA, US) equipped with a fused silica capillary column (ZB 5MSI, Phenomenex, Torrance, CA, US) and a flame ionization detector (FID). Helium with high purity $(99.999 \%)$ was used as a carrier gas with a head pressure of $250 \mathrm{kPa}$. The injection was made in split-less mode with $1.0 \mu \mathrm{L}$ injection volume. The temperature of the injection port was set at $165^{\circ} \mathrm{C}$. The initial oven temperature was set at $90^{\circ} \mathrm{C}$ and then ramped up to $175^{\circ} \mathrm{C}$ at a rate of $10^{\circ} \mathrm{C} / \mathrm{min}$, where it was held constant for $3 \mathrm{~min}$. The temperature of the FID detector was set to $330^{\circ} \mathrm{C}$. The detection limit for GC-FID was $1 \mathrm{mg} / \mathrm{L}$.

The extracts containing $<1 \mathrm{mg} / \mathrm{L}$ sulfolane were analyzed using a Shimazhu QP2010SP gas chromatograph-mass spectrometer (GC-MS) (Shimazhu, Kyoto, Japan) equipped with a ZB 5MSI column. Helium with high purity $(99.999 \%)$ was used as a carrier gas with a constant flow of $1.07 \mathrm{~mL} / \mathrm{min}$. The injection was made in split-less mode with $1.0 \mu \mathrm{L}$ injection volume. The temperature of the injection port was set at $250{ }^{\circ} \mathrm{C}$. The initial oven temperature was set to $90^{\circ} \mathrm{C}$ and held for $2 \mathrm{~min}$, ramped up to $160{ }^{\circ} \mathrm{C}$ at a rate of $10^{\circ} \mathrm{C} / \mathrm{min}$, and finally increased to $280{ }^{\circ} \mathrm{C}$ at a rate of $20{ }^{\circ} \mathrm{C} / \mathrm{min}$, where it was held constant for $2 \mathrm{~min}$. The mass spectrometer was set to only scan for selective characteristic ions with $\mathrm{m} / \mathrm{z}$ equal to 41,56 , and 120 . The detection limit for GC-MS was $10 \mu \mathrm{g} / \mathrm{L}$.

For DOC analysis, each 20-mL of water sample was analyzed using an Apollo 9000 Combustion TOC Analyzer (Teledyne Tekmar, Mason, OH, US) equipped with an autosampler. The detection limit was $0.1 \mathrm{mg} / \mathrm{L}$.

\section{6. $\mathrm{H}_{2} \mathrm{O}_{2}$ Measurement}

The range of $\mathrm{H}_{2} \mathrm{O}_{2}$ concentration in the field water samples was initially determined by using MQuant ${ }^{\mathrm{TM}}$ Peroxide test strips obtained from EMD Millipore (Burlington, VT, US). Test strips with two ranges were used: $0.5-25$ and $10-100 \mathrm{mg} / \mathrm{L}$. The hydrogen peroxide in the water samples was further quantified with a hydrogen peroxide test kit (Model HYP-1) purchased from Hach (London, $\mathrm{ON}$, Canada). The measurement range of the test kit was $1-10 \mathrm{mg} / \mathrm{L}$ with an accuracy of $1 \mathrm{mg} / \mathrm{L}$. Samples needed to be diluted with ultrapure water before quantification if they contained hydrogen peroxide above $10 \mathrm{mg} / \mathrm{L}$.

\section{Results and Discussions}

\subsection{Degradation of Sulfolane in a $\mathrm{UV} / \mathrm{H}_{2} \mathrm{O}_{2}$ Pilot System}

Results of degradation of sulfolane in the reservoir using $\mathrm{UV} / \mathrm{H}_{2} \mathrm{O}_{2}$ are presented in Figure 2. As was noted, sulfolane degraded in both groundwaters. The initial sulfolane concentration in Water I and Water II was $260 \mu \mathrm{g} / \mathrm{L}$ and $12.6 \mathrm{mg} / \mathrm{L}$. $\mathrm{H}_{2} \mathrm{O}_{2}$ concentrations in the reservoir were maintained between 25 and $35 \mathrm{mg} / \mathrm{L}$. After $8 \mathrm{~h}$ of operation, $84 \%$ of sulfolane degraded in Water I and $95 \%$ of sulfolane degraded in Water II. To determine the kinetics of sulfolane degradation, the data were fitted into both first-order and second-order kinetics scenarios in Figure 2a. It is seen from the figure, a larger R-square ( $>0.99)$ was obtained when the data were fitted to first-order kinetics. Therefore, the first-order degradation kinetics was chosen in this paper. The first-order degradation rate constant determined for Waters I and II were $0.22 \mathrm{~h}^{-1}$ and $0.41 \mathrm{~h}^{-1}$, respectively. The dissolved organic carbon in Water II was also measured throughout the experiments, and the results are reported in Figure $2 \mathrm{~b}$. After $8 \mathrm{~h}$ of operation, more than $38 \%$ of DOC degraded from Water II. The reduction of DOC indicates that sulfolane degradation daughter products can also be oxidized by hydroxyl radicals, leading to complete mineralization. Mehrabani-Zeinabad et al. [7] achieved around 20\% of DOC removal when $95 \%$ of sulfolane was degraded in ultrapure water by $\mathrm{UV} / \mathrm{H}_{2} \mathrm{O}_{2}$. A higher DOC/sulfolane removal ratio was observed in our study, as the groundwater contained other dissolved organic contaminants 
that were less recalcitrant than sulfolane. It was estimated that sulfolane only accounted for $38 \%$ of dissolved organic matter in Water II after being spiked with sulfolane.

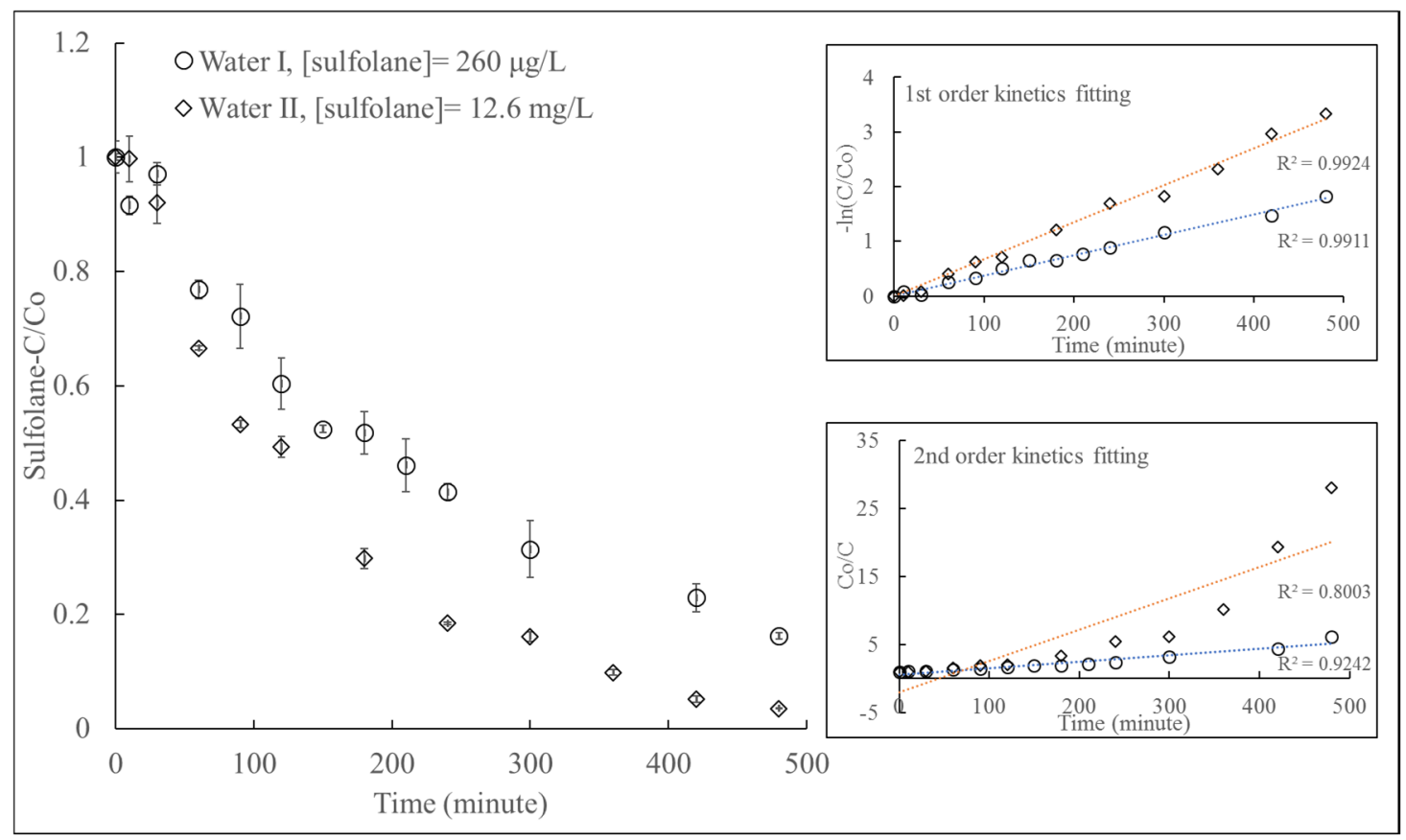

(a)

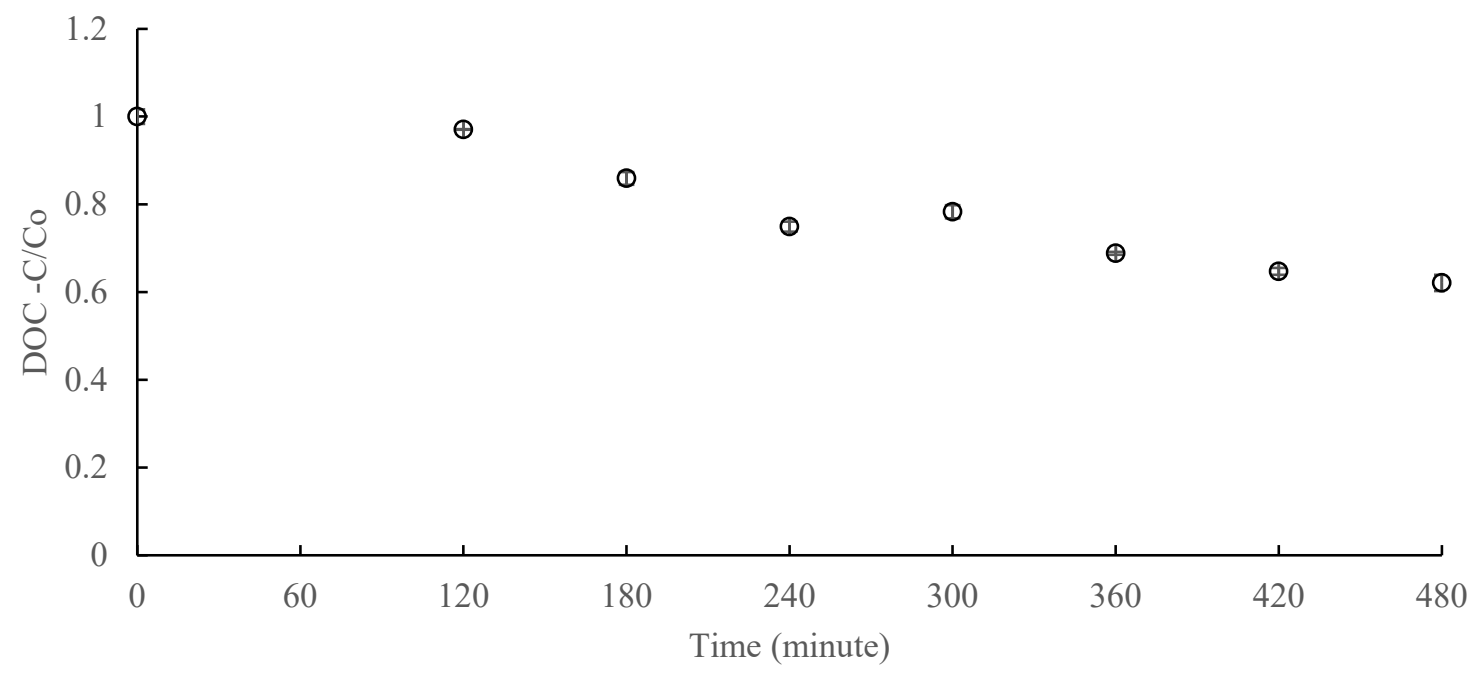

(b)

Figure 2. Degradation of sulfolane in the $\mathrm{UV} / \mathrm{H}_{2} \mathrm{O}_{2}$ pilot system-recirculation mode; $\left[\mathrm{H}_{2} \mathrm{O}_{2}\right]=25-35$ $\mathrm{mg} / \mathrm{L}$. (a) Sulfolane, (b) dissolved organic carbon (DOC) for Water II; initial DOC was $13.28 \mathrm{mg} / \mathrm{L}$.

The concept of electrical energy per order of reduction $\left(E_{\mathrm{EO}}\right)$ introduced by Bolton et al. [16] was used in this paper to determine the energy required for sulfolane degradation. $E_{\mathrm{EO}}$ is the amount of electrical energy required to degrade $90 \%$ (one order of magnitude) of contaminants per cubic meter of water, and the unit is $\mathrm{kWh} \mathrm{m}^{-3}$ order $^{-1}$. $E_{\mathrm{EO}}$ is determined in a batch reactor and flow-through reactor as follows. 
Batch Reactor:

$$
E_{\mathrm{EO}}=\frac{P \times t}{V \times \log _{10}\left(\frac{C_{0}}{C_{t}}\right)}=\frac{2.3026 \times P}{V \times k}
$$

where $P$ is the power of $\mathrm{UV}$ unit $(\mathrm{kW}) ; V$ is the volume of water $\left(\mathrm{m}^{3}\right), t$ is the operational time $(\mathrm{h}), C_{o}$ is the initial concentration of sulfolane $(\mathrm{mg} / \mathrm{L}), C_{t}$ is the concentration of sulfolane after " $t$ " irradiation, and $k$ is the first-order reaction rate constant $\left(\mathrm{h}^{-1}\right)$.

For a flow-through reactor:

$$
E_{\mathrm{EO}}=\frac{P}{Q \times \log _{10}\left(\frac{C_{\text {in }}}{C_{\text {out }}}\right)}
$$

where $Q$ is the water flow rate $\left(\mathrm{m}^{3} / \mathrm{h}\right), C_{\text {in }}$ is the influent concentration of sulfolane $(\mathrm{mg} / \mathrm{L})$, and $C_{\text {out }}$ is the effluent concentration of sulfolane $(\mathrm{mg} / \mathrm{L})$.

The experiments conducted in this section were in recirculation modes, and the volume of the reservoir was much larger than the reaction chamber. Therefore, they can be considered as batch experiments. The $E_{\mathrm{EO}}$ for Waters I and II was calculated to be $7.5 \mathrm{kWh} \mathrm{m}^{-3}$ order $^{-1}$ and $4.0 \mathrm{kWh} \mathrm{m}^{-3}$ order $^{-1}$, respectively. These values fall within the typical ranges of $E_{\mathrm{EO}}$ for treating other groundwater pollutants by using $\mathrm{UV} / \mathrm{H}_{2} \mathrm{O}_{2}$. Electrical energy per order of reduction is pollutant-specific and depends on the characteristics of the contaminated water, which are also influenced by the UV lamp technology, the reactor configuration, flow conditions, and other operational parameters [17,18]. Sutherland et al. [19] found that the $E_{\mathrm{EO}}$ for treating Methyl tert-butyl ether (MTBE) in groundwater varied from 1.2 to $247 \mathrm{kWh} \mathrm{m}^{-3}$ order $^{-1}$. $E_{\mathrm{EO}}$ for treating tri(2-chloroethyl) phosphate (TCEP) in groundwater was reported to be $0.5-1.4 \mathrm{kWh} \mathrm{m}^{-3}$ order $^{-1}$ by Santoro et al. [20]. $E_{\mathrm{EO}}$ for treating surface water is usually lower than that for groundwater. Lee et al. [21] investigated the $E_{\mathrm{EO}}$ for 16 micropollutants in the secondary wastewater effluents and found their values were mostly less than $1 \mathrm{kWh} \mathrm{m}^{-3}$ order $^{-1}$. Lekkerkerker-Teunissen et al. [18] have obtained similar $E_{\mathrm{EO}}$ by using low-pressure mercury lamps for 15 estrogenic chemicals, and their values varied from 0.23 to $1.34 \mathrm{kWh}$ $\mathrm{m}^{-3}$ order $^{-1}$. It is noted that the UV lamps used in our study were low-pressure mercury lamps, of which the $E_{\mathrm{EO}}$ is usually lower than that obtained with medium pressure mercury lamps $[18,22,23]$.

\subsection{Iron in the Groundwater}

For the pilot experiments, groundwater was pumped and placed in above-ground containers. It was observed that the color of Water I turned yellow and the water became turbid after it was brought to the surface (Figure 3a). Water analyses (see Table 1) indicated the presence of iron, manganese, and other dissolved elements in groundwater. Although under an acidic conditon, the dissolved iron can react with hydrogen peroxide to generate hydroxyl radicals, which is known as the Fenton reaction [24]. Under the neutral or alkaline condition, iron becomes unstable and precipitates out [25]. Manganese has been reported as a catalyst to decompose hydrogen peroxide to generate hydroperoxide/superoxide anions [26]. However, no evidence suggested that hydroxyl radicals can be generated through this process. Our lab analysis also confirmed that no sulfolane degradation occurred in such groundwater with hydrogen peroxide.

The oxidative environment of ambient water, as the water pumped out, led to iron oxidation and precipitation [27]. These precipitates caused two major problems: (1) UVT of the water was decreased, reducing the process efficiency. In this pilot test, the UVT of Water I was around 60\%, while the UVT of Water II was around 80\%. (2) The precipitates deposited in the reaction chamber (Figure 3b) fouled the protective sleeves of UV lamps (Figure 3c). Iron is considered as a key element of fouling UV lamp sleeves, which can form stronger complexes than calcium [28,29]. In this pilot study, the groundwater was not pretreated before AOP treatment due to the lack of ability to treat large amounts of groundwater contained $\mathrm{mg} / \mathrm{L}$-levels of iron. In order to achieve a higher treatment efficiency, a pretreatment step is suggested to remove dissolved iron and soften the groundwater. 


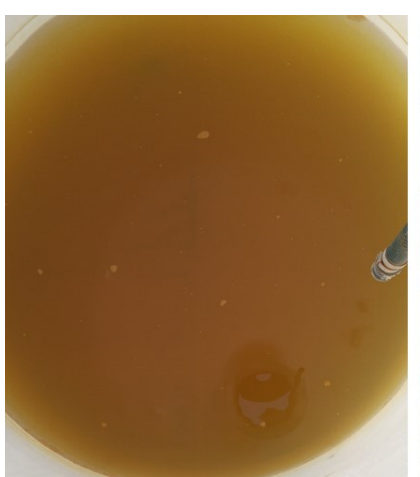

(a)

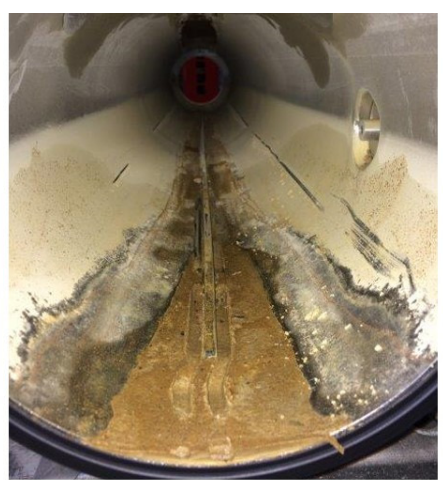

(b)

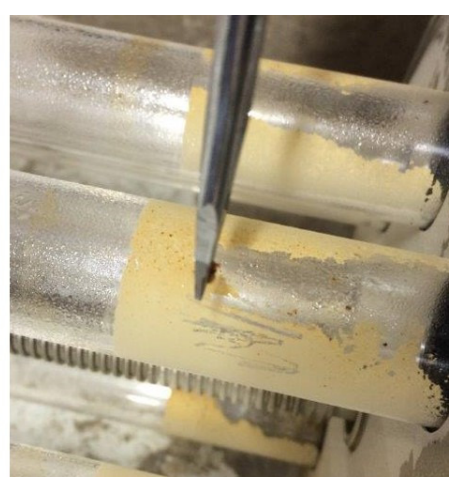

(c)

Figure 3. Challenges caused by dissolved iron and others: (a) picture taken from the HDPE reservoir; (b) picture taken from the UV chamber; (c) picture taken from the protection sleeve of UV lamps.

\subsection{Influent Sulfolane Concentration}

In order to study the impact of influent sulfolane concentration on its degradation by $\mathrm{UV} / \mathrm{H}_{2} \mathrm{O}_{2}$, the experiment was conducted with Water I in a recirculation mode. The concentration of sulfolane in both influent water and effluent water was determined. The influent concentration of sulfolane decreased as the operational time increased; consequently, different influent concentrations were obtained at different operational times. The sulfolane concentration in the effluent, along with sulfolane degradation for different influent concentrations $(42-260 \mu \mathrm{g} / \mathrm{L})$, are shown in Table 2. It was found that about $21 \%$ to $40 \%$ of influent sulfolane were degraded. This variation was not large enough to undermine first-order kinetic assumptions.

Table 2. Removal percentages for different influent sulfolane concentrations in Water I.

\begin{tabular}{ccc}
\hline Influent Sulfolane Conc. $(\boldsymbol{\mu g} / \mathbf{L})$ & Effluent Sulfolane Conc. $(\mu \mathrm{g} / \mathrm{L})$ & Removal Percentage \\
\hline 260 & 200 & 23 \\
252 & 173 & 31 \\
238 & 184 & 23 \\
200 & 159 & 21 \\
188 & 126 & 33 \\
136 & 104 & 24 \\
134 & 98 & 27 \\
120 & 86 & 28 \\
108 & 71 & 34 \\
82 & 63 & 23 \\
60 & 36 & 40 \\
42 & 28 & 33 \\
\hline
\end{tabular}

\subsection{Water Flow Rate}

The effect of the water flow rate on sulfolane degradation in single-pass mode was investigated, and the results are presented in Table 3. The results showed that sulfolane degradation decreased as the flow rate increased. With $46 \mathrm{~L} / \mathrm{min}$ of water flow rate, $36 \%$ of sulfolane degraded by $40 \mathrm{mg} / \mathrm{L} \mathrm{of} \mathrm{H}_{2} \mathrm{O}_{2}$ and $50 \%$ of sulfolane degraded by $80 \mathrm{mg} / \mathrm{L}$ of $\mathrm{H}_{2} \mathrm{O}_{2}$. As the water flow rate decreased to $15.1 \mathrm{~L} / \mathrm{min}$,

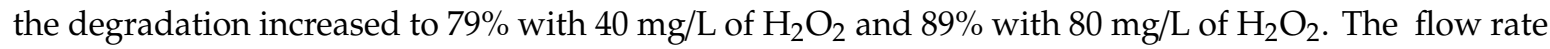
can impact the residence time of water in the UV reaction chamber, leading to different UV irradiation exposures. When the flow rate decreased from 46 to $15.1 \mathrm{~L} / \mathrm{min}$, the retention time in the UV chamber was increased by a factor of 3, leading to a higher sulfolane removal percentage. As shown in Table 3, for the same hydrogen peroxide concentration, the $E_{\mathrm{EO}}$ calculated from two different flow rates based on Equation (2) are similar, which confirmed that the system can be scaled up based on first-order 
degradation kinetics. The performance of $\mathrm{UV} / \mathrm{H}_{2} \mathrm{O}_{2}$ also depends on the water/contaminant mass transfer through the photoreactor. Higher efficiency of the treatment system is associated with better mass transfer [30,31]. For most photoreactors, a higher water flow leads to a better mass transfer. In this pilot test, the photoreactor was equipped with a motionless mixer; thus, the impact of water flow on mass transfer was minimal.

Table 3. The effect of water flow rate on sulfolane degradation in Water III in single-pass mode.

\begin{tabular}{|c|c|c|c|c|}
\hline [Sulfolane] $\mu \mathrm{g} / \mathrm{L}$ & {$\left[\mathrm{H}_{2} \mathrm{O}_{2}\right] \mathrm{mg} / \mathrm{L}$} & Flow Rate (L/min) & Removal Percentage & Calculated $E_{\mathrm{EO}}\left(\mathrm{kWh} \mathrm{m}^{-3}\right.$ order $\left.^{-1}\right)$ \\
\hline 200 & 40 & 46 & 36 & 4.0 \\
\hline 200 & 40 & 15.1 & 79 & 3.6 \\
\hline 200 & 80 & 46 & 50 & 2.6 \\
\hline 200 & 80 & 15.1 & 89 & 2.5 \\
\hline
\end{tabular}

\subsection{Introduction of Ozone into a $\mathrm{UV} / \mathrm{H}_{2} \mathrm{O}_{2}$ System}

Ozone was introduced to the $\mathrm{UV} / \mathrm{H}_{2} \mathrm{O}_{2}$ system to enhance the sulfolane degradation rate. Results of degradation of sulfolane using a combination of different oxidants $\left(\mathrm{O}_{3}, \mathrm{UV} / \mathrm{O}_{3}, \mathrm{O}_{3} / \mathrm{H}_{2} \mathrm{O}_{2}, \mathrm{UV} / \mathrm{H}_{2} \mathrm{O}_{2}\right.$, and $\mathrm{UV} / \mathrm{O}_{3} / \mathrm{H}_{2} \mathrm{O}_{2}$ ) are presented in Figure 4. Among the different combinations tested, the results showed $\mathrm{UV} / \mathrm{H}_{2} \mathrm{O}_{2}$ and $\mathrm{UV} / \mathrm{O}_{3} / \mathrm{H}_{2} \mathrm{O}_{2}$ have the fastest sulfolane degradation. The addition of ozone did not improve the sulfolane degradation rate by $\mathrm{UV} / \mathrm{H}_{2} \mathrm{O}_{2}$. Yu et al. [6] reported that a combination of $\mathrm{H}_{2} \mathrm{O}_{2} / \mathrm{O}_{3} / \mathrm{UV}$ could result in a degradation rate 1.8 times faster than that obtained by using $\mathrm{UV} / \mathrm{H}_{2} \mathrm{O}_{2}$, which were not observed in this field test. This is possibly because the ozone dosage per unit volume in the pilot test was much smaller than that reported by Yu et al. [6]. The ozone feeding rate $\left(10 \mathrm{~g} / \mathrm{h} / \mathrm{m}^{3}\right) \mathrm{in}$ this study was only $0.3 \%$ of that described by the same previous cited study. In addition, the pilot test was conducted in an open tank where the ozone escaped from the system. To enhance the sulfolane degradation requires a pressurized ozonation system and a significant increase in the ozone feeding rate, which might make the process less cost-effective.

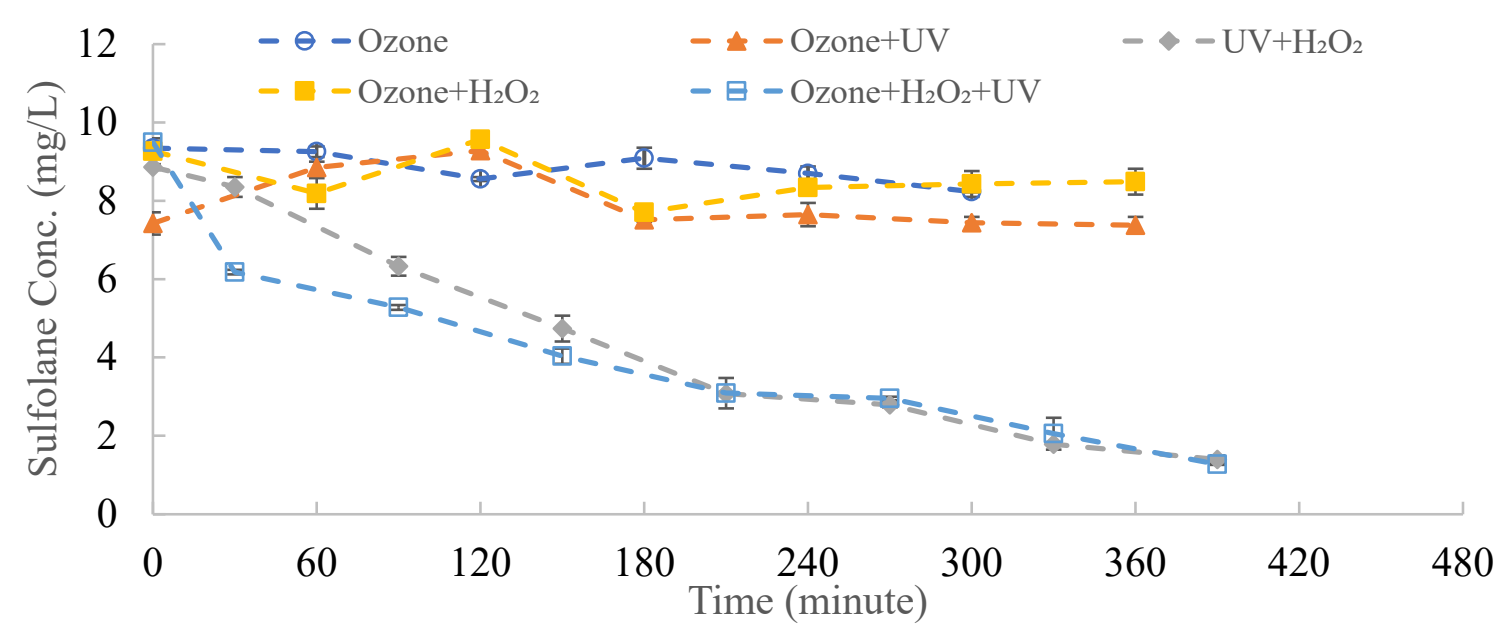

Figure 4. Degradation of sulfolane in Water II with combinations of different oxidants: $\left[\mathrm{H}_{2} \mathrm{O}_{2}\right]=40 \mathrm{mg} / \mathrm{L}$, ozone rate $=30 \mathrm{~g} / \mathrm{h}$.

3.6. Optimization of $\mathrm{H}_{2} \mathrm{O}_{2}$

\subsubsection{The Effect of $\mathrm{H}_{2} \mathrm{O}_{2}$ Concentration on Sulfolane Degradation}

Six different $\mathrm{H}_{2} \mathrm{O}_{2}$ concentrations $(10,18,40,110,180$, and $240 \mathrm{mg} / \mathrm{L})$ were investigated for treating Water II containing $9.5 \mathrm{mg} / \mathrm{L}$ of sulfolane in single-pass mode. The sulfolane removal and the $E_{\mathrm{EO}}$ for different $\mathrm{H}_{2} \mathrm{O}_{2}$ concentrations are presented in Figure 5. It is found that an increase in $\mathrm{H}_{2} \mathrm{O}_{2}$ concentration leads to an increase in sulfolane degradation and a decrease in $E_{\mathrm{EO}}$, which indicates less electricity requirement. With $10 \mathrm{mg} / \mathrm{L}$ of $\mathrm{H}_{2} \mathrm{O}_{2}, 14.2 \%$ of sulfolane degraded while the $E_{\mathrm{EO}}$ was 
$11.6 \mathrm{kWh} \mathrm{m}^{-3}$ order $^{-1}$. As the concentration of $\mathrm{H}_{2} \mathrm{O}_{2}$ increased to $40 \mathrm{mg} / \mathrm{L}$, the sulfolane degradation enhanced to $59 \%$ while $E_{\mathrm{EO}}$ dropped to $2.0 \mathrm{kWh} \mathrm{m}^{-3}$ order $^{-1}$. Further increase in $\mathrm{H}_{2} \mathrm{O}_{2}$ concentration did not improve the degradation or the $E_{\mathrm{EO}}$. This is because the hydroxyl radical concentration does not increase steadily with $\mathrm{H}_{2} \mathrm{O}_{2}$ concentration due to recombination and scavenging effect, and this limits the sulfolane degradation [6,32]. The critical hydrogen peroxide concentration depends on the type of water, type of contaminants, concentration of contaminants, and configuration of the photoreactor. The reporting operating concentration of $\mathrm{H}_{2} \mathrm{O}_{2}$ in a pilot-scale $\mathrm{UV} / \mathrm{H}_{2} \mathrm{O}_{2}$ system is $0-50 \mathrm{mg} / \mathrm{L}$ for treating domestic wastewater [12,13], $0-10 \mathrm{mg} / \mathrm{L}$ for surface water [11,14], and 0-153 $\mathrm{mg} / \mathrm{L}$ for treating groundwater [15].

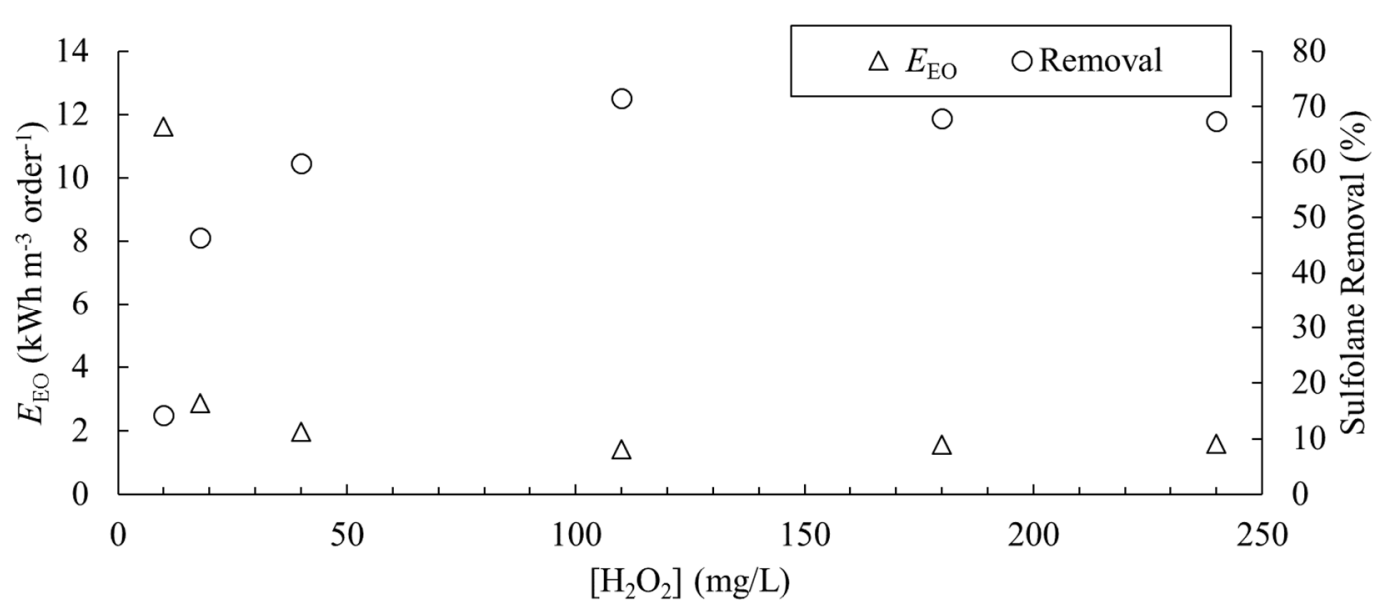

Figure 5. $E_{\mathrm{EO}}$ and sulfolane removal versus the $\mathrm{H}_{2} \mathrm{O}_{2}$ concentration in Water II, [sulfolane] $=9.5 \mathrm{mg} / \mathrm{L}$, $\mathrm{Q}=46 \mathrm{~L} / \mathrm{min}$.

\subsubsection{Decomposition of Hydrogen Peroxide}

The concentrations of $\mathrm{H}_{2} \mathrm{O}_{2}$ before entering the UV reactor and upon exiting the reactor for two different water flow rates are presented in Figure 6. The relationship between $\mathrm{H}_{2} \mathrm{O}_{2}$ concentration before UV and after UV was modeled by the linear regression. The R-squared for the linear regression model are 0.9969 for water flow rate equal to $46 \mathrm{~L} / \mathrm{min}$, and 0.9862 for water flow rate equal to $26 \mathrm{~L} / \mathrm{min}$. The result shows that the decomposition of $\mathrm{H}_{2} \mathrm{O}_{2}$ in groundwater by ultraviolet irradiation follows first-order degradation kinetics as the $\mathrm{H}_{2} \mathrm{O}_{2}$ percentage removal is independent of its influent $\mathrm{H}_{2} \mathrm{O}_{2}$ concentration. A higher decomposition rate of $\mathrm{H}_{2} \mathrm{O}_{2}$ was obtained at a lower water flow rate. Around $14 \%$ of $\mathrm{H}_{2} \mathrm{O}_{2}$ decomposed after passing through the UV chamber with a flow rate of $46 \mathrm{~L} / \mathrm{min}$, while around $23 \%$ of $\mathrm{H}_{2} \mathrm{O}_{2}$ decomposed when the flow rate decreased to $26 \mathrm{~L} / \mathrm{min}$. The decomposition of $\mathrm{H}_{2} \mathrm{O}_{2}$ increased as the UV exposure duration increased. It is noted that for the same water flow rate (46 $\mathrm{L} / \mathrm{min}$ ) and the same influent $\mathrm{H}_{2} \mathrm{O}_{2}$ concentration, sulfolane removal percentage in Water II (as shown in Figure 5) was higher than hydrogen peroxide removal percentage, indicating that excess $\mathrm{H}_{2} \mathrm{O}_{2}$ can be present in the treated groundwaters, which need to be further managed.

\subsubsection{Operational Cost Model}

In this section, an operational cost model for treating sulfolane through the $\mathrm{UV} / \mathrm{H}_{2} \mathrm{O}_{2}$ process is developed. The following five assumptions were made to simplify the cost model: (1) the total operational cost consists of the electricity cost, $\mathrm{H}_{2} \mathrm{O}_{2}$ cost, and UV lamp replacement cost; (2) the labor cost is not considered in this model; (3) market price of $\mathrm{H}_{2} \mathrm{O}_{2}$, electricity, and UV lamps do not fluctuate; (4) the lifetime of UV lamps and the lamp efficiency are constant; (5) the variation of UV radiation from UV lamps is negligible throughout their lifespan. 


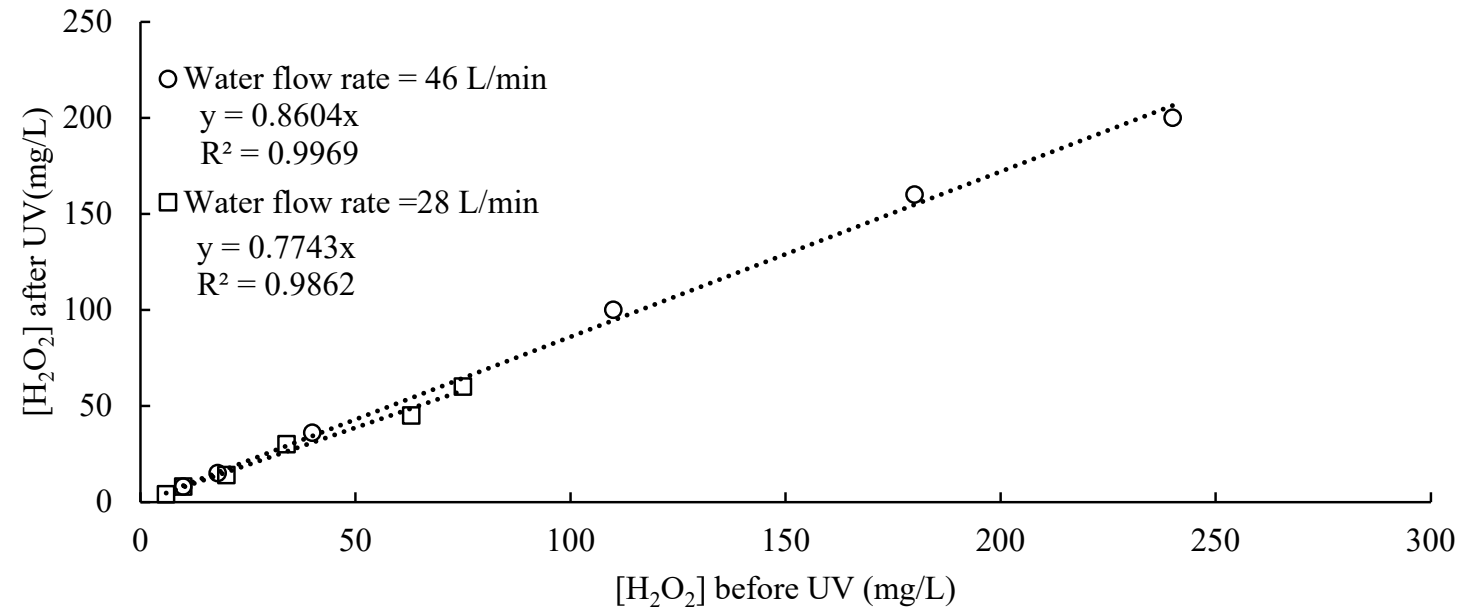

Figure 6. The concentration of $\mathrm{H}_{2} \mathrm{O}_{2}$ before UV chamber versus its concentration after UV chamber: Water II, [sulfolane] $=9.5 \mathrm{mg} / \mathrm{L}$.

All costs are normalized to Canadian dollar (CAD) per $\mathrm{m}^{3}$ of treated water. The equations for calculating $\mathrm{H}_{2} \mathrm{O}_{2}$ cost $\left(C_{h}\right)$, electricity cost $\left(C_{e}\right)$, and UV lamp cost $\left(C_{l}\right)$ are provided in Equations (3)-(5), respectively.

$$
C_{h}=\frac{c_{\mathrm{H}_{2} \mathrm{O}_{2}} \times P r_{\mathrm{H}_{2} \mathrm{O}_{2}}}{\eta}
$$

where $c_{\mathrm{H}_{2} \mathrm{O}_{2}}$ is the operating $\mathrm{H}_{2} \mathrm{O}_{2}$ concentration $\left(\mathrm{kg} / \mathrm{m}^{3}\right), P r_{\mathrm{H}_{2} \mathrm{O}_{2}}$ is the unit price of $\mathrm{H}_{2} \mathrm{O}_{2}$ solution $(\mathrm{CAD} / \mathrm{kg})$, and $\eta$ is the purity of $\mathrm{H}_{2} \mathrm{O}_{2}$ solution.

$$
C_{e}=\alpha \times E_{\mathrm{EO}} \times P r_{e}
$$

where $P r_{e}$ is the unit price of electricity (CAD/kWh), $\alpha$ is the number of log reduction required to meet the sulfolane groundwater guideline.

$$
C_{l}=\frac{P r_{l} \times N_{l}}{t_{l} \times Q}=\frac{P r_{l} \times N_{l} \times \alpha \times E_{\mathrm{EO}}}{t_{l} \times P}
$$

where $P r_{l}$ is the unit price of a lamp (CAD), $Q$ is the average designed water flow rate $\left(\mathrm{m}^{3} / \mathrm{h}\right), N_{l}$ is the number of lamps in the UV unit, and $t_{l}$ is the lifetime of UV lamps (h).

The total operational $\operatorname{cost}\left(C_{\text {total }}\right)$ is a sum of the three costs mentioned above:

$$
C_{\text {total }}=C_{h}+C_{e}+C_{l}=\frac{C_{\mathrm{H}_{2} \mathrm{O}_{2}} \times P r_{\mathrm{H}_{2} \mathrm{O}_{2}}}{\eta}+\alpha \times E_{E O} \times P r_{e}+\frac{P r_{l} \times N_{l} \times E_{\mathrm{EO}}}{t_{l} \times P}
$$

Equation (6) reveals that the total operational cost of $\mathrm{UV} / \mathrm{H}_{2} \mathrm{O}_{2}$ system is influenced by operating $\mathrm{H}_{2} \mathrm{O}_{2}$ concentration, the number of $\log$ reduction, $E_{\mathrm{EO}}$, the market price of hydrogen peroxide, electricity and UV lamps, the lifetime of UV lamps, and the power input of the UV unit.

Based on Figure 5, an empirical relationship $\left(E_{\mathrm{EO}}=f\left(c_{\mathrm{H}_{2} \mathrm{O}_{2}}\right)\right)$ between $E_{\mathrm{EO}}$ and concentration of hydrogen peroxide can be established. The total operational cost as a function of $\mathrm{H}_{2} \mathrm{O}_{2}$ concentration is given as

$$
C_{\text {total }}=\frac{c_{\mathrm{H}_{2} \mathrm{O}_{2}} \times \operatorname{Pr}_{\mathrm{H}_{2} \mathrm{O}_{2}}}{\eta}+\alpha \times f\left(c_{\mathrm{H}_{2} \mathrm{O}_{2}}\right) \times P r_{e}+\frac{P r_{l} \times N_{l} \times \alpha \times f\left(c_{\mathrm{H}_{2} \mathrm{O}_{2}}\right)}{t_{l} \times P}
$$

The values of different parameters shown in Table 4 and the $E_{\mathrm{EO}}-\mathrm{H}_{2} \mathrm{O}_{2}$ relationship in Figure 5 were used for estimating the total operational cost to achieve one log reduction of sulfolane. Different costs versus the concentration of hydrogen peroxide are presented in Figure 7. It shows that cost increased as $\mathrm{H}_{2} \mathrm{O}_{2}$ concentrations were either more or less than $40 \mathrm{mg} / \mathrm{L}$. Thus, in this study, the optimum 
concentration of $\mathrm{H}_{2} \mathrm{O}_{2}$ is $40 \mathrm{mg} / \mathrm{L}$, with the operational cost of $0.35 \mathrm{CAD} / \mathrm{m}^{3}$. It is noted that the optimum concentration here refers to the concentration of $\mathrm{H}_{2} \mathrm{O}_{2}$, leading to the minimal total operational cost for one order reduction.

Table 4. Parameter estimation for cost calculation.

\begin{tabular}{cc}
\hline Parameters & Value \\
\hline Unit price of $\mathrm{H}_{2} \mathrm{O}_{2}(50 \%$ purity $)$ & $0.8 \mathrm{CAD} / \mathrm{kg}$ \\
Unit price of electricity & $0.08 \mathrm{CAD} / \mathrm{kWh}$ \\
Lifetime of UV lamps & $12,000 \mathrm{~h}$ \\
Price of UV lamp & $200 \mathrm{CAD}$ each \\
Number of UV lamp & 8 \\
Number of log reduction & 1 \\
\hline
\end{tabular}

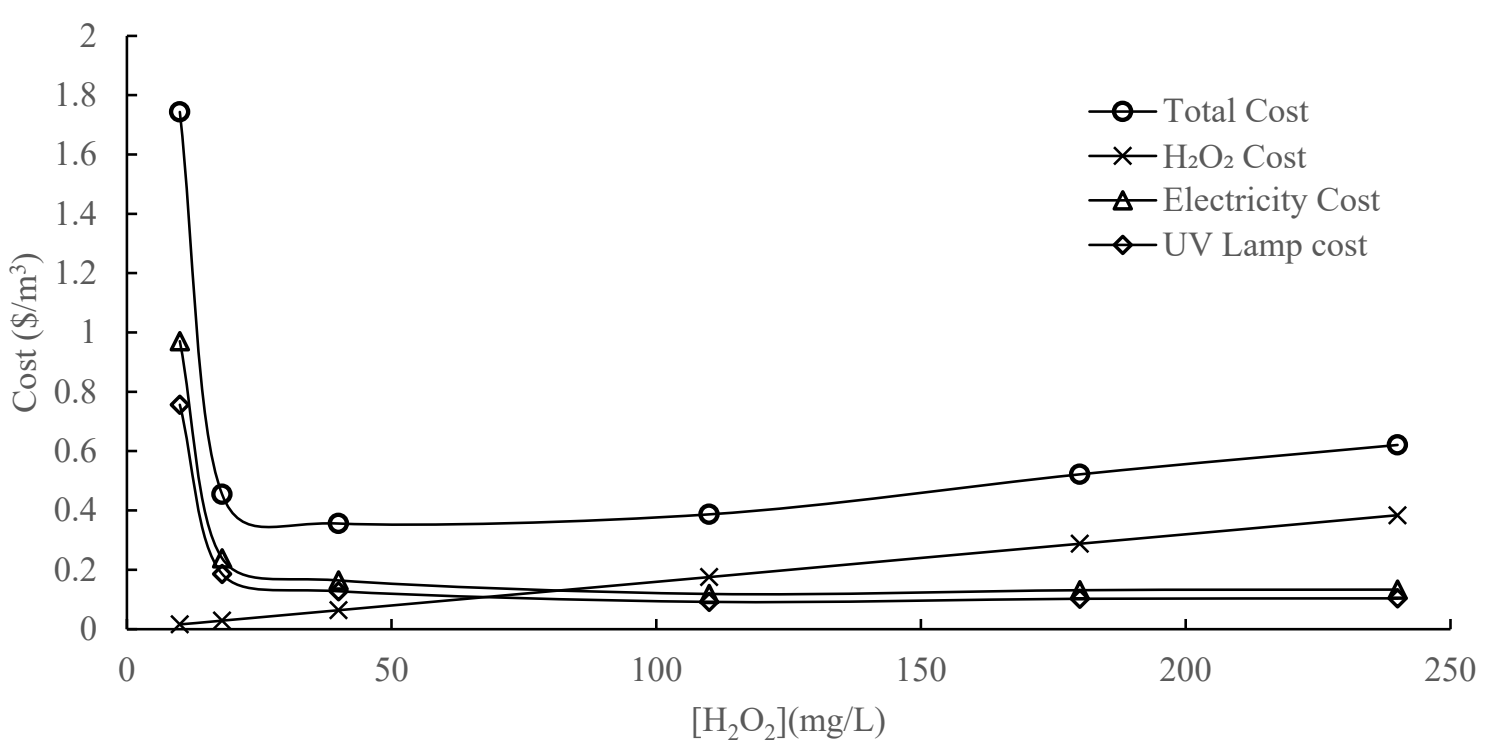

Figure 7. $\mathrm{H}_{2} \mathrm{O}_{2}$ cost, electricity energy cost, UV lamp cost, and total cost versus $\left[\mathrm{H}_{2} \mathrm{O}_{2}\right]$ : Water II, [sulfolane] $=9.5 \mathrm{mg} / \mathrm{L}$.

\subsection{Selection of the Right Size of UV System to Treat Sulfolane in Groundwater}

A proper size of UV system is required to achieve the groundwater remediation goal. A stepwise procedure to choose the size of the UV unit for treating sulfolane in contaminated groundwater is shown in Figure 8 and described below:

Step 1. Develop a contaminant transport model to determine the average groundwater extraction rates and the remediation period $(t)$ to meet the sulfolane guideline $\left(C_{g}\right)$ in groundwater. The required treatment capacity $(Q)$ is equal to average groundwater extraction rates.

Step 2. Determine the average concentration of sulfolane $\left(C_{a}\right)$ in the extracted groundwater. It is expected that the concentration of sulfolane in the extracted groundwater changes over time; therefore, the water samples need to be routinely collected and analyzed.

Step 3. Establish the site-specific $E_{\mathrm{EO}}-\mathrm{H}_{2} \mathrm{O}_{2}$ relationship. The $E_{\mathrm{EO}}-\mathrm{H}_{2} \mathrm{O}_{2}$ relationship in this paper can be used as a reference for treating similarly contaminated groundwater. However, if the contaminated water has a very different composition, experiments should be conducted to obtain $E_{\mathrm{EO}}$ for different $\mathrm{H}_{2} \mathrm{O}_{2}$ concentrations.

Step 4. Calculate the total operational cost for different $\mathrm{H}_{2} \mathrm{O}_{2}$ based on Equation (7).

Step 5. Identify the optimal concentration of $\mathrm{H}_{2} \mathrm{O}_{2}$ by minimizing the total operational cost, as described in Section 3.6.3.

Step 6. Find the $E_{\mathrm{EO}}$ corresponding to the optimal $\mathrm{H}_{2} \mathrm{O}_{2}$ from Step 3. 
Step 7. Determine the power of the UV unit required to treat the contaminated water based on the following Equation (8)

$$
P=\frac{E_{\mathrm{EO}} \times Q}{\log _{10}\left(\frac{C_{a}}{C_{g}}\right)}
$$

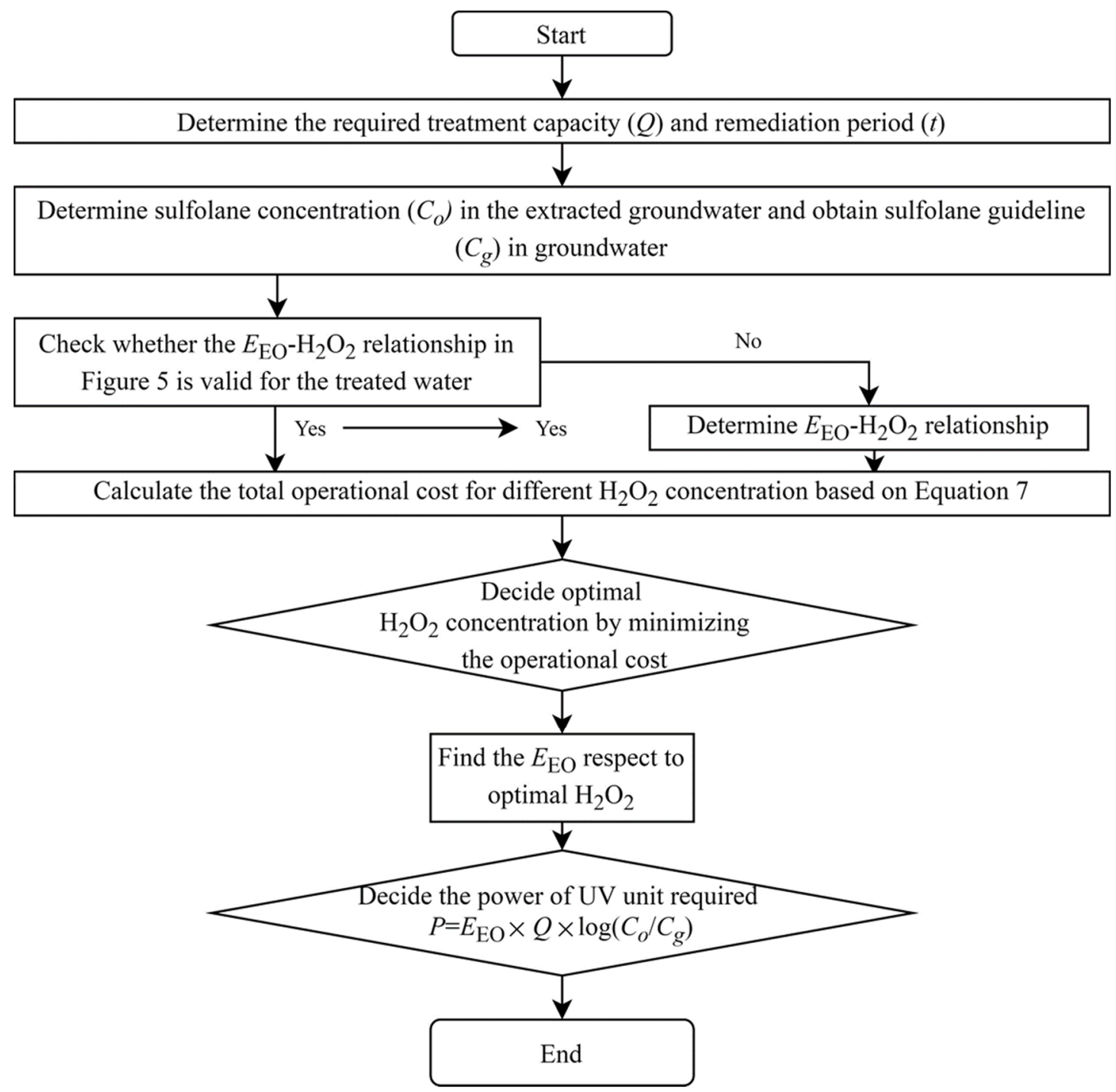

Figure 8. A flowchart for designing a $\mathrm{UV} / \mathrm{H}_{2} \mathrm{O}_{2}$ treatment system.

\section{Conclusions}

In this paper, a field pilot-scale $\mathrm{UV} / \mathrm{H}_{2} \mathrm{O}_{2}$ was successfully evaluated in treating sulfolane in the groundwater. The findings from this field pilot test can be useful for system scale-up and full application of the technology. The following key conclusions are drawn from this pilot study:

- The field pilot test confirmed that a pilot $\mathrm{UV} / \mathrm{H}_{2} \mathrm{O}_{2}$ system can successfully treat different sulfolane-contaminated groundwaters. The lowest $E_{\mathrm{EO}}$ obtained in this field pilot study was $1.4 \mathrm{kWh} \mathrm{m}^{-3}$ order $^{-1}$.

- The sulfolane degradation rate was not significantly impacted by the initial concentration.

- The addition of $\mathrm{O}_{3}$ at a rate of $10 \mathrm{~g} / \mathrm{h} / \mathrm{m}^{3}$ did not enhance sulfolane degradation by $\mathrm{UV} / \mathrm{H}_{2} \mathrm{O}_{2}$.

- Consumption of hydrogen peroxide in the pilot $\mathrm{UV} / \mathrm{H}_{2} \mathrm{O}_{2}$ system followed first-order kinetics. 
- An operational cost model is developed. The optimal $\mathrm{H}_{2} \mathrm{O}_{2}$ concentration in this study was determined to be $40 \mathrm{mg} / \mathrm{L}$, leading to an operational cost of $0.35 \mathrm{CAD} / \mathrm{m}^{3}$.

- A systematic procedure is presented to select the right size of UV unit.

Author Contributions: Methodology, L.Y. and G.A.; investigation, L.Y., S.I., and I.K.; data curation, L.Y. and S.I.; writing-original draft preparation, L.Y. and S.I.; writing—review and editing, L.Y. and G.A.; supervision, G.A.; project administration, G.A. All authors have read and agreed to the published version of the manuscript.

Funding: This research was funded by the Natural Sciences and Engineering Research Council of Canada, grant number 10012306.

Acknowledgments: The authors acknowledge the financial support provided by NSERC and Bonavista Energy Corporation to conduct this research.

Conflicts of Interest: The authors declare no conflict of interest.

\section{References}

1. Della Monica, M.; Jannelli, L.; Lamanna, U. Physicochemical properties of sulfolane. J. Phys. Chem. 1968, 72, 1068-1071. [CrossRef]

2. Stewart, O.; Minnear, L. Sulfolane Technical Assistance and Evaluation Report; Oasis Environmental: Anchorage, AK, USA, 2010.

3. Zhu, Z.H.; Sun, M.L.; Li, Z.S.; Yang, Z.C.; Zhang, T.B.; Heng, Z.C.; Xiao, B.L.; Li, Q.Y.; Peng, Q.Y.; Dong, Y.H. An investigation of the maximum allowable concentration of sulfolane in surface water. Hua Xi Yi Ke Da Xue Хие Bao 1987, 18, 376-380. [PubMed]

4. Gordon, C.J.; Dyer, R.S.; Long, M.D.; Fehlner, K.S. Effect of sulfolane on behavioral and autonomic thermoregulation in the rat. J. Toxicol. Environ. Health Part A 1985, 16, 461-468. [CrossRef] [PubMed]

5. Shah, S.M.; Wahba, M.; Yu, L.; Achari, G.; Habibi, H.R. Health Impact Assessment of Sulfolane on Embryonic Development of Zebrafish (Danio rerio). Toxics 2019, 7, 42. [CrossRef] [PubMed]

6. Yu, L.; Mehrabani-Zeinabad, M.; Achari, G.; Langford, C.H. Application of UV based advanced oxidation to treat sulfolane in an aqueous medium. Chemosphere 2016, 160, 155-161. [CrossRef] [PubMed]

7. Mehrabani-Zeinabad, M.; Yu, L.; Achari, G.; Langford, C.H. Mineralisation of sulfolane by $\mathrm{UV} / \mathrm{O}_{3} / \mathrm{H}_{2} \mathrm{O}_{2}$ in a tubular reactor. J. Environ. Eng. Sci. 2016, 11, 44-51. [CrossRef]

8. Izadifard, M.; Achari, G.; Langford, C.H. Degradation of sulfolane using activated persulfate with UV and UV-Ozone. Water Res. 2017, 125, 325-331. [CrossRef]

9. Brandão, M.; Yu, L.; Garcia, C.; Achari, G. Advanced Oxidation Based Treatment of Soil Wash Water Contaminated with Sulfolane. Water 2019, 11, 2152. [CrossRef]

10. Khan, M.F.; Yu, L.; Achari, G.; Tay, J.H. Degradation of sulfolane in aqueous media by integrating activated sludge and advanced oxidation process. Chemosphere 2019, 222, 1-8. [CrossRef]

11. Chu, X.; Xiao, Y.; Hu, J.; Quek, E.; Xie, R.; Pang, T.; Xing, Y. Pilot-scale UV/ $\mathrm{H}_{2} \mathrm{O}_{2}$ study for emerging organic contaminants decomposition. Rev. Environ. Health 2016, 31, 71-74. [CrossRef]

12. De La Cruz, N.; Esquius, L.; Grandjean, D.; Magnet, A.; Tungler, A.; De Alencastro, L.; Pulgarin, C. Degradation of emergent contaminants by $\mathrm{UV}, \mathrm{UV} / \mathrm{H}_{2} \mathrm{O}_{2}$ and neutral photo-Fenton at pilot scale in a domestic wastewater treatment plant. Water Res. 2013, 47, 5836-5845. [CrossRef]

13. Miklos, D.; Hartl, R.; Michel, P.; Linden, K.; Drewes, J.E.; Hübner, U. UV/ $\mathrm{H}_{2} \mathrm{O}_{2}$ process stability and pilot-scale validation for trace organic chemical removal from wastewater treatment plant effluents. Water Res. 2018, 136, 169-179. [CrossRef]

14. Sarathy, S.R.; Stefan, M.I.; Royce, A.; Mohseni, M. Pilot-scale UV/ $\mathrm{H}_{2} \mathrm{O}_{2}$ advanced oxidation process for surface water treatment and downstream biological treatment: Effects on natural organic matter characteristics and DBP formation potential. Environ. Technol. 2011, 32, 1709-1718. [CrossRef] [PubMed]

15. Hirvonen, A.; Tuhkanen, T.; Ettala, M.; Korhonen, S.; Kalliokoski, P. Evaluation of a Field-Scale $\mathrm{UV} / \mathrm{H}_{2} \mathrm{O}_{2}$-Oxidation System for the Purification of Groundwater Contaminated with PCE. Environ. Technol. 1998, 19, 821-828. [CrossRef]

16. Bolton, J.R.; Bircher, K.G.; Tumas, W.; Tolman, C.A. Figures-of-merit for the technical development and application of advanced oxidation technologies for both electric- and solar-driven systems (IUPAC Technical Report). Pure Appl. Chem. 2001, 73, 627-637. [CrossRef] 
17. Hansen, K.M.S.; Andersen, H.R. Energy Effectiveness of Direct UV and UV/ $\mathrm{H}_{2} \mathrm{O}_{2}$ Treatment of Estrogenic Chemicals in Biologically Treated Sewage. Available online: https://www.hindawi.com/journals/ijp/2012/ 270320/ (accessed on 8 January 2020).

18. Lekkerkerker-Teunissen, K.; Knol, A.H.; Derks, J.G.; Heringa, M.B.; Houtman, C.J.; Hofman-Caris, C.H.M.; Beerendonk, E.F.; Reus, A.; Verberk, J.Q.J.C.; Van Dijk, J. Pilot Plant Results with Three Different Types of UV Lamps for Advanced Oxidation. Ozone Sci. Eng. 2013, 35, 38-48. [CrossRef]

19. Sutherland, J.; Adams, C.; Kekobad, J. Treatment of MTBE by air stripping, carbon adsorption, and advanced oxidation: Technical and economic comparison for five groundwaters. Water Res. 2004, 38, 193-205. [CrossRef] [PubMed]

20. Santoro, D.; Raisee, M.; Moghaddami, M.; Ducoste, J.J.; Sasges, M.; Liberti, L.; Notarnicola, M. Modeling Hydroxyl Radical Distribution and Trialkyl Phosphates Oxidation in UV $-\mathrm{H}_{2} \mathrm{O}_{2}$ Photoreactors Using Computational Fluid Dynamics. Environ. Sci. Technol. 2010, 44, 6233-6241. [CrossRef]

21. Lee, Y.; Gerrity, D.; Lee, M.; Gamage, S.; Pisarenko, A.; Trenholm, R.A.; Canonica, S.; Snyder, S.A.; Von Gunten, U. Organic Contaminant Abatement in Reclaimed Water by $\mathrm{UV} / \mathrm{H}_{2} \mathrm{O}_{2}$ and a Combined Process Consisting of $\mathrm{O}_{3} / \mathrm{H}_{2} \mathrm{O}_{2}$ Followed by $\mathrm{UV} / \mathrm{H}_{2} \mathrm{O}_{2}$ : Prediction of Abatement Efficiency, Energy Consumption, and Byproduct Formation. Environ. Sci. Technol. 2016, 50, 3809-3819. [CrossRef]

22. Ijpelaar, G.F.; Harmsen, D.J.; Beerendonk, E.F.; Van Leerdam, R.C.; Metz, D.H.; Knol, A.H.; Fulmer, A.; Krijnen, S. Comparison of Low Pressure and Medium Pressure UV Lamps for UV/ $\mathrm{H}_{2} \mathrm{O}_{2}$ Treatment of Natural Waters Containing Micro Pollutants. Ozone Sci. Eng. 2010, 32, 329-337. [CrossRef]

23. Li, K.; Hokanson, D.R.; Crittenden, J.C.; Trussell, R.R.; Minakata, D. Evaluating UV/ $\mathrm{H}_{2} \mathrm{O}_{2}$ processes for methyl tert-butyl ether and tertiary butyl alcohol removal: Effect of pretreatment options and light sources. Water Res. 2008, 42, 5045-5053. [CrossRef] [PubMed]

24. Pignatello, J.J.; Oliveros, E.; Mackay, A. Advanced Oxidation Processes for Organic Contaminant Destruction Based on the Fenton Reaction and Related Chemistry. Crit. Rev. Environ. Sci. Technol. 2006, 36, 1-84. [CrossRef]

25. Yu, L.; Achari, G.; Langford, C.H.; Keir, I. A feasibility study on sulfolane degradation in groundwater using neutral fenton catalysts. In Proceedings of the CSCE 2016, London, ON, Canada, 1-4 June 2016.

26. Do, S.-H.; Batchelor, B.; Lee, H.-K.; Kong, S.-H. Hydrogen peroxide decomposition on manganese oxide (pyrolusite): Kinetics, intermediates, and mechanism. Chemosphere 2009, 75, 8-12. [CrossRef] [PubMed]

27. Hem, J.D. Stability Field Diagrams as Aids in Iron Chemistry Studies. J. Am. Water Work. Assoc. 1961, 53, 211-232. [CrossRef]

28. Peng, J.; Qiu, Y.; Gehr, R. Characterization of Permanent Fouling on the Surfaces of UV Lamps Used for Wastewater Disinfection. Water Environ. Res. 2005, 77, 309-322. [CrossRef] [PubMed]

29. Wait, I.; Johnston, C.T.; Blatchleyiii, E.; Iii, E.R.B. The influence of oxidation reduction potential and water treatment processes on quartz lamp sleeve fouling in ultraviolet disinfection reactors. Water Res. 2007, 41, 2427-2436. [CrossRef]

30. Saien, J.; Moradi, V.; Soleymani, A.R. Investigation of a jet mixing photo-reactor device for rapid dye discoloration and aromatic degradation via UV/ $\mathrm{H}_{2} \mathrm{O}_{2}$ process. Chem. Eng. J. 2012, 183, 135-140. [CrossRef]

31. Tabrizi, G.B.; Mehrvar, M. Pilot-plant study for the photochemical treatment of aqueous linear alkylbenzene sulfonate. Sep. Purif. Technol. 2006, 49, 115-121. [CrossRef]

32. Daneshvar, N.; Behnajady, M.A.; Asghar, Y.Z. Photooxidative degradation of 4-nitrophenol (4-NP) in $\mathrm{UV} / \mathrm{H}_{2} \mathrm{O}_{2}$ process: Influence of operational parameters and reaction mechanism. J. Hazard. Mater. 2007, 139, 275-279. [CrossRef]

(C) 2020 by the authors. Licensee MDPI, Basel, Switzerland. This article is an open access article distributed under the terms and conditions of the Creative Commons Attribution (CC BY) license (http://creativecommons.org/licenses/by/4.0/). 